\title{
Modeling and Statistical Analysis of Piston End of Connecting Rod, Using Ansys Software
}

\author{
Dnyaneshwar.V.Bhadane ${ }^{1}$, Nikhil S. Patel ${ }^{2}$, Khatik Imran Ahmad Shaikh Rafiq ${ }^{3}$ \\ ${ }^{1,2,3}$ UG students, Department of Mechanical Engineering, Jamia Institute of Engg \& Management Studies Akkalkuwa, \\ Maharashtra,
}

Received on: 16 July, 2021

Revised on: 15 August, 2021

Published on: 17 August, 2021

\begin{abstract}
In today's world scenario, there is tremendous development in the field of automobile and every day, there is new invention is arrived to do better out transport facility. It is found that the prize of fuel is growing widely, so every company is trying to make the vehicle more fuel efficient and having best quality and comfort for the user. Also company may concentrated on very important fact, service after sale it is consider spinal code in the field of automobile. Most of the company may spend their 50\% of their income on research and development to make their vehicle better. Previously this task is very expensive in absence of recent technology, for testing and design like $C A D / C A M$ and the analysis software like Ansys software, the prediction is very difficult about any product. Also CFD is play major role for the aerodynamic designing for the automobile. Using Different CAD/CAM software one can design the product as per the requirement, can also manufacture easily on CNC machine. In previous days, once the product is design it will be at least few years remains in the market. But now a days, in every six month new model will be launched by the company due the advancement in the automotive sector. This project work is based on bi-metallic component used in automobile; there are lot many bi-metallic components used in automobile application. In this case, connecting rod is identified with brass bush at its eye end. It induces the thermal stress in the material to overcome this serious problem. Hence it is suggested that the alternative material for bushing.
\end{abstract}

Keyword : ANSYS, CATIA, FEA, Stress Analysis, Connecting rod.

\section{I- INTRODUCTION}

The automobile engine connecting rod is a high volume production critical component. It connects reciprocating piston to rotating crankshaft, transmitting the thrust of piston to the crankshaft. Every vehicle that uses an internal combustion engine requires at least one connecting rod depending upon the number of cylinders in the engine. To reduce the obliquity of the connecting rod with cylinder axis, its lengths should be kept as long as possible. Reduced obliquity decreases the oscillatory angular motion of the connecting rod about it small end, thereby decreasing the piston side thrust and improving the reciprocating balance of the engine. To provide maximum rigidity with minimum weight the main cross section is made an I- section. This I- section is made to blends smoothly into the two rod ends called the small end (Piston end) and big end (crank end). The Connecting rod for automotive applications is typically manufactured by forging from either wrought steel or powdered metal. The misalignment of connecting rod is due to wear or long period causes a pounding sound. Also if any fault occurs in connecting rod assembly, 


\section{International Journal of Innovations in Engineering and Science, www.ijies.net}

whole assembly is to be replaced. Hence it becomes necessary that design of connecting rod should be done very carefully. The current project deals with the finite element analysis of small piston end of connecting rod for the calculations of thermal stresses acting on bimetallic component that is bush made up of brass metal and piston end which is of forged steel. Due to difference between the thermal expansion rates of brass and steel, results in failure of the component.

\section{II- OBJECTIVE OF THE PROJECT}

This project deals with the thermal analysis of the piston end of connecting rod. Now a days the connecting rod used in automobiles is made up of forged steel and a brass bush is press fitted in it. The thermal expansion rate of these two metals are differs from each other. At piston end, the temperature increases from 500 to $5500 \mathrm{C}$, so at this temperature, the deformation of piston end takes place as bush tends to expand more due to high expansion rate. This leads to develop tensile stresses in piston end and compressive stresses in bush. As brass expands, rapidly it also contracts rapidly; this develops the clearance between small end and bush which reduces the life of connecting rod. The aim of this project is to determine the von misses stresses, deformation, stress intensity, strain energy at the junction. As we created 3D model using modeling software CATIAV5R20, then import the CATIA model in ANSYS V12 by converting Catia file into igs format file. Analyzed the component using ANSYS, so for the result, we conclude the best suited material for bush material.

\section{III- MATERIAL PROPERTIES OF CONNECTING ROD}

The following materials are used for study and analysis of modelling \& thermal analysis of connecting rod. The dimensions of the selected connecting rod are found using vernier calipers, screw gauge and are tabulated in the table. 1 The modeled connecting rod is as shown in fig.1.

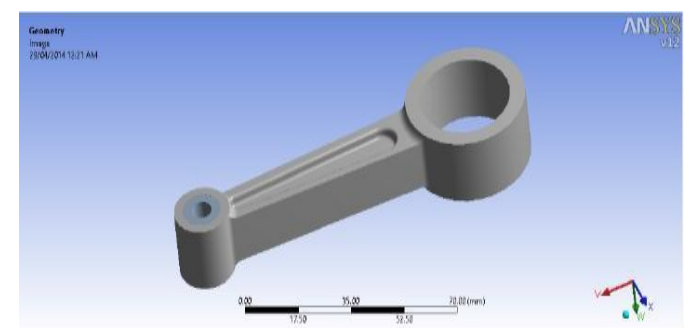

Fig.1- Model of Connecting Rod
Table 1-Material Properties of Connecting Rod

\begin{tabular}{|c|c|c|c|c|}
\hline $\begin{array}{c}\text { Sr. } \\
\text { No }\end{array}$ & $\begin{array}{c}\text { Properti } \\
\text { es }\end{array}$ & Brass & Steel & Cast Iron \\
\hline 1. & $\begin{array}{c}\text { Young's } \\
\text { Modulus }\end{array}$ & $\begin{array}{c}1.1 \times 10^{5} \mathrm{~N} / \\
\mathrm{m}^{2}\end{array}$ & $\begin{array}{c}1.93 \times 10^{5} \mathrm{~N} \\
/ \mathrm{m}^{2}\end{array}$ & $\begin{array}{c}1.1 \times 10^{5} \mathrm{~N} / \\
\mathrm{m}^{2}\end{array}$ \\
\hline 2. & $\begin{array}{c}\text { Poisons } \\
\text { Ratio }\end{array}$ & 0.34 & 0.31 & 0.28 \\
\hline 3. & Density & $\begin{array}{c}8216 \\
\mathrm{Kg} / \mathrm{m}^{3}\end{array}$ & $\begin{array}{c}7860 \\
\mathrm{Kg} / \mathrm{m}^{3}\end{array}$ & $\begin{array}{c}7870 \\
\mathrm{Kg} / \mathrm{m}^{3}\end{array}$ \\
\hline 4. & $\begin{array}{c}\text { Thermal } \\
\text { Expansi } \\
\text { on }\end{array}$ & $\begin{array}{c}1.67 \mathrm{e}-5 \\
/{ }^{0} \mathrm{~K}\end{array}$ & $1.17 \mathrm{e}-5 /{ }^{0} \mathrm{~K}$ & $\begin{array}{c}1.21 \mathrm{e}-5 /^{0} \\
\mathrm{~K}\end{array}$ \\
\hline 5. & $\begin{array}{c}\text { Thermal } \\
\text { Conduct } \\
\text { ivity }\end{array}$ & 1.8 & 1.7 & 3.5 \\
\hline 6. & $\begin{array}{c}\text { Yield } \\
\text { Strength }\end{array}$ & $\begin{array}{c}3.5 \mathrm{e}+8 \\
\mathrm{~N} / \mathrm{m}^{2}\end{array}$ & $\begin{array}{c}2.5 \mathrm{e}+8 \\
\mathrm{~N} / \mathrm{m}^{2}\end{array}$ & $\begin{array}{c}3.1 \mathrm{e}+8 \\
\mathrm{~N} / \mathrm{m}^{2}\end{array}$ \\
\hline \multicolumn{4}{|c|}{} \\
\end{tabular}

Table 2-. Configuration of Engine To Which Connecting Rod Belongs

\begin{tabular}{|c|c|c|}
\hline $\begin{array}{c}\mathrm{Sr} \\
\text { No }\end{array}$ & Parameters & Values \\
\hline 1 & Length of connecting rod & $125 \mathrm{~mm}$ \\
\hline 2 & Outer diameter of Big end & $40 \mathrm{~mm}$ \\
\hline 3 & Inner diameter of Big end & $30.19 \mathrm{~mm}$ \\
\hline 4 & Outer diameter of Small end & $18.5 \mathrm{~mm}$ \\
\hline 5 & Mass of the Piston Assembly & $0.082 \mathrm{Kg}$ \\
\hline 6 & Mass of the connecting rod & $0.086 \mathrm{Kg}$ \\
\hline 7 & Maximum Gas Pressure & $2.2 \mathrm{MPa}$ \\
\hline
\end{tabular}

\section{IV - MODELLING OF CONNECTING ROD BY USING CATIA V5R20}

The connecting rod of Hero Honda splendor market model available is selected for the present investigation purpose. According to the dimensions, the model of the connecting rod is developed using CATIAV5R20.

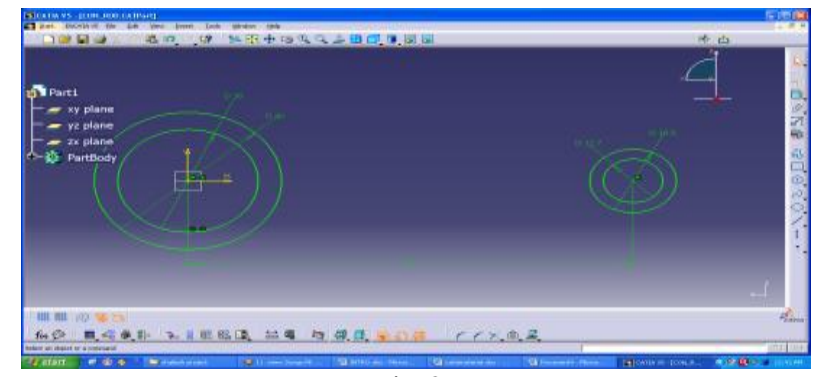

Fig.2. 


\section{International Journal of Innovations in Engineering and Science, www.ijies.net}

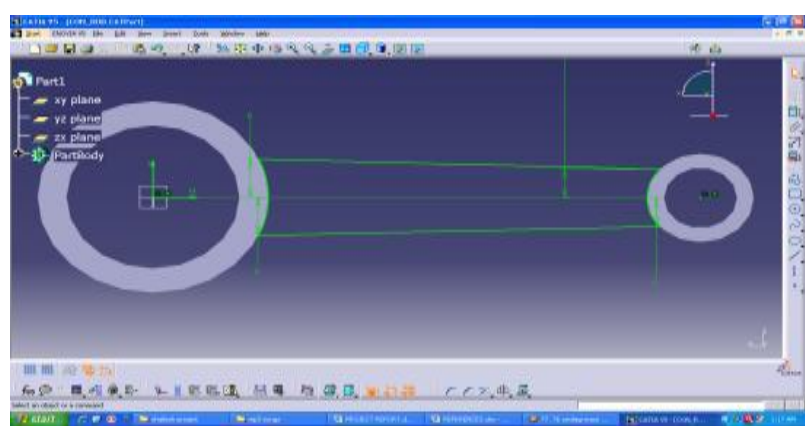

Fig.3.

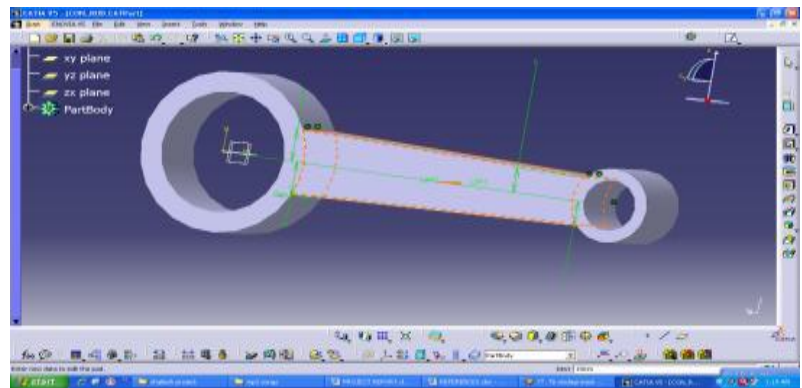

Fig.4.

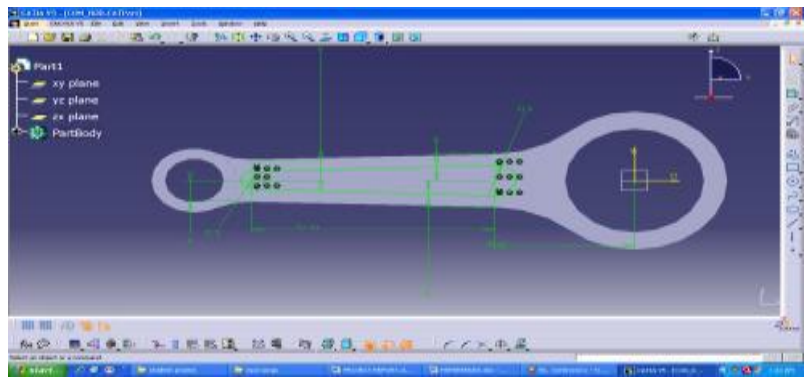

Fig.5.

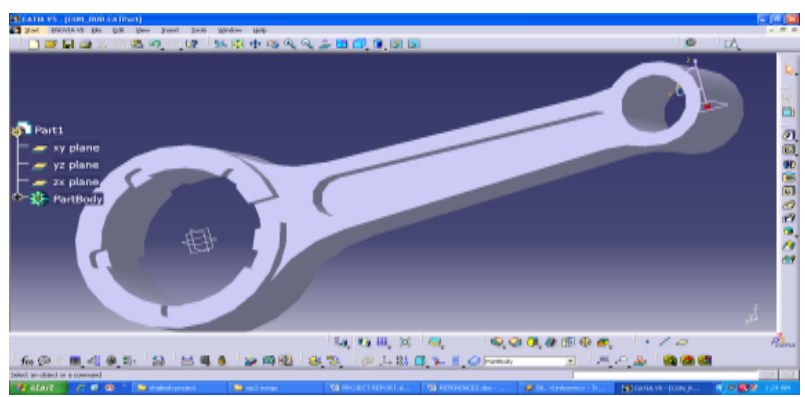

Fig.6.

\section{V- ANSYS V12 SIMULATION REPORT}

The main goals of analysis are for finding the actual stresses acting on bimetallic component on piston end of connecting rod.

A) Analysis carried out by the Software ANSYS of Brass bush \& Forged steel connecting rod

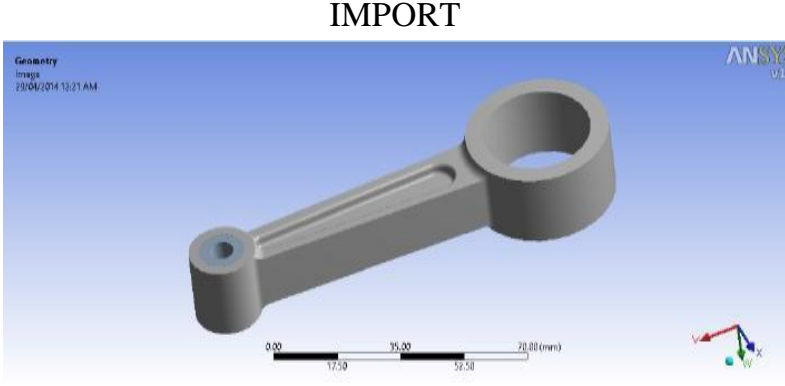

Fig 7- Import Model in ANSYS

\section{MESHING}

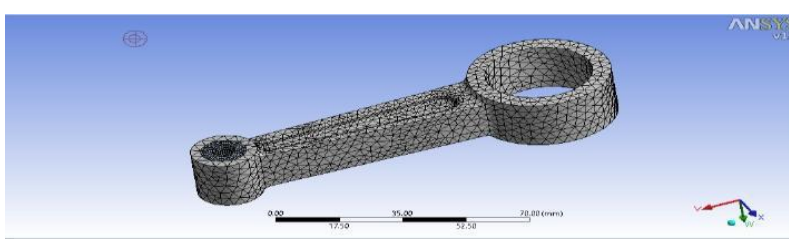

Fig 8- Meshing of the Piston end

\section{BOUNDRY CONDITIONS}

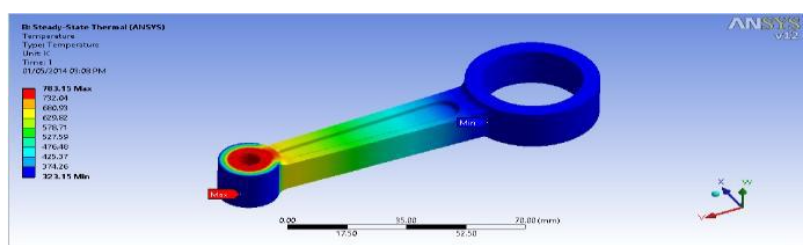

Fig 9- Appling thermal boundary conditions DEFORMATION

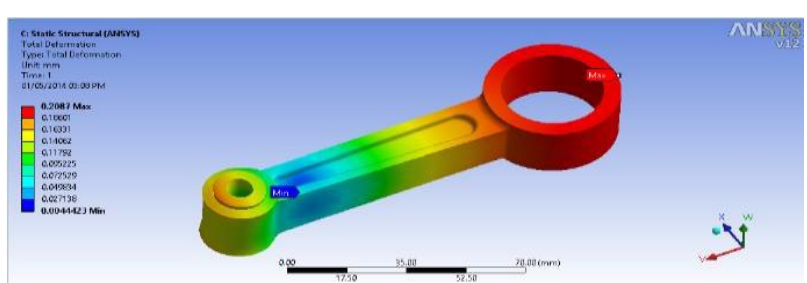

Fig10 - Deformation of Piston end DEVELOPMENT OF STRESSES

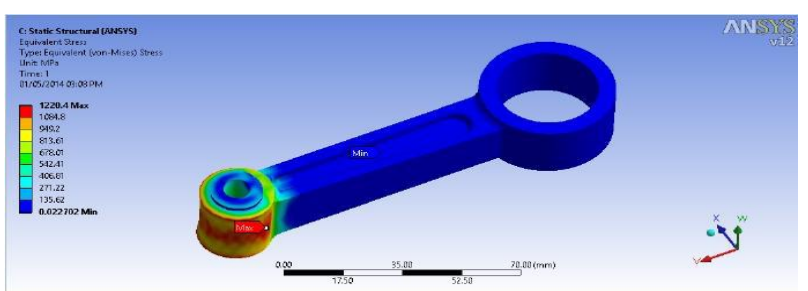

Fig.11- Vonmisses Stresses developed in Piston End 


\section{International Journal of Innovations in Engineering and Science, www.ijies.net}

DEVELOPMENT OF STRESS INTENSITY

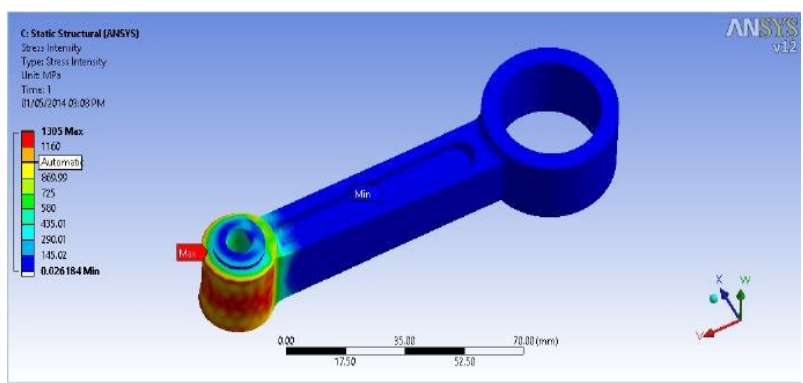

Fig.12- Stress Intensity developed in Piston End

DEVELOPMENT OF STRAIN ENERGY

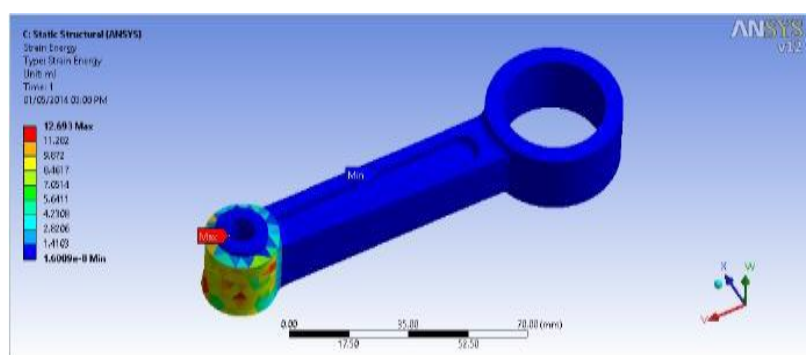

Fig 13- Strain Energy developed in Piston end

(B) Analysis carried out by the Software ANSYS of Gray Cast Iron bush \&Forged steel connecting rod

IMPORT

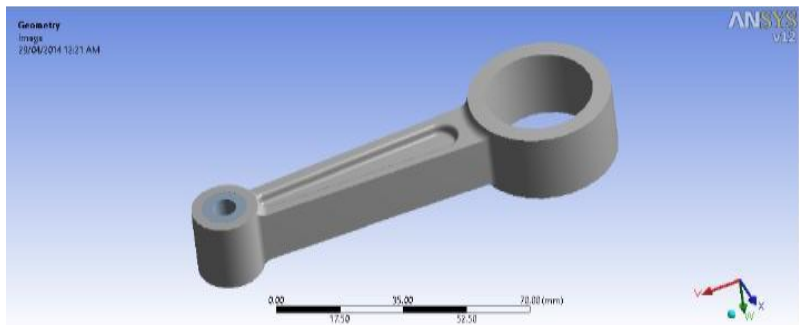

Fig 14- Import Model in ANSYS

MESHING

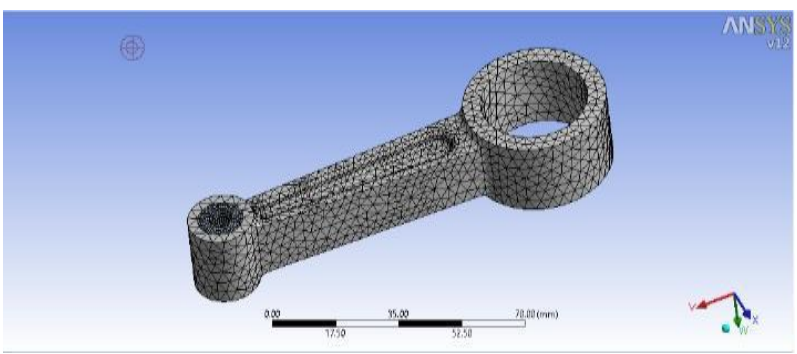

Fig 15-Meshing of the Piston end

\section{BOUNDRY CONDITIONS}

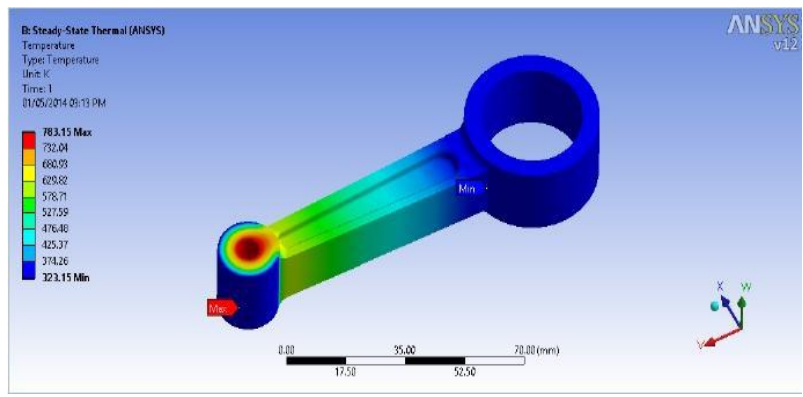

Fig 16- Appling thermal Boundary Conditions

DEFORMATION

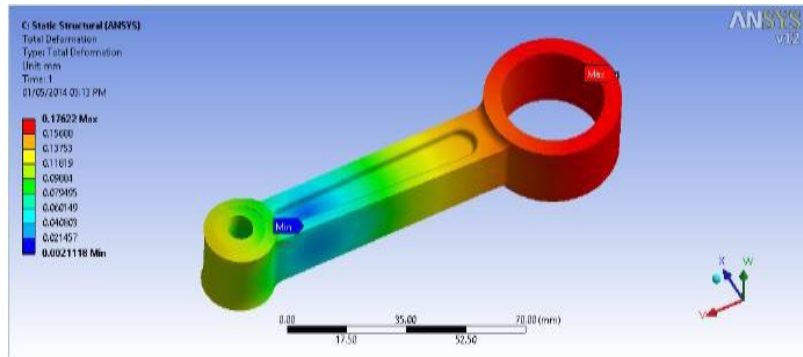

Fig.17- Deformation of piston end

DEVELOPMENT OF STRESSES

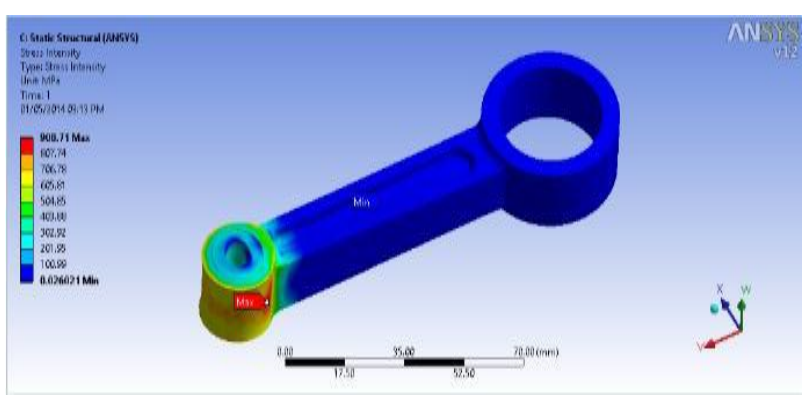

Fig.18- Von misses Stresses developed in Piston End DEVELOPMENT OF STRAIN ENERGY

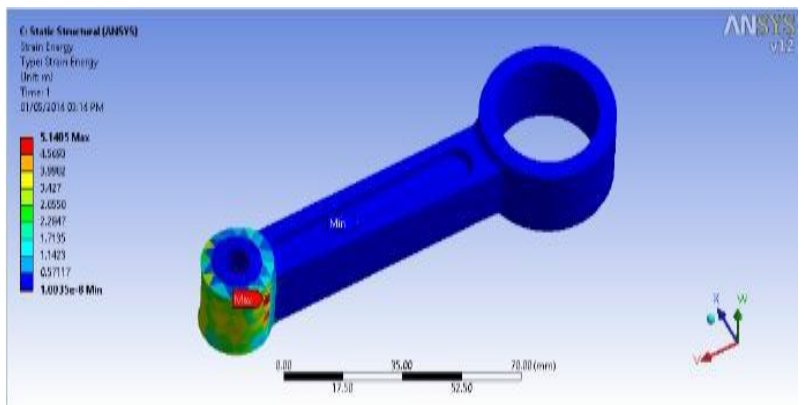

Fig 19-Strain Energy developed in Piston end. 
Vol. 6, No. 10, 2021, PP. 107-111

International Journal of Innovations in Engineering and Science, www.ijies.net

\section{VI - COMPARISION TABLE}

Table 3- (a) Comparison Results of Brass Bush \&

Forged Steel of Connecting rod.

\begin{tabular}{|c|c|c|c|}
\hline $\begin{array}{l}\text { Sr. } \\
\text { No } \\
\end{array}$ & Property & $\begin{array}{c}\text { Theoretical } \\
\text { Value }\end{array}$ & $\begin{array}{c}\text { Analytical } \\
\text { Value by } \\
\text { ANSYS } \\
\end{array}$ \\
\hline 1 & $\begin{array}{l}\text { Deformation in } \\
\text { Grey Cast Iron }\end{array}$ & $0.0971 \mathrm{~mm}$ & $\begin{array}{c}\text { O.O9884m } \\
\mathrm{m}\end{array}$ \\
\hline 2 & $\begin{array}{c}\text { Deformation in } \\
\text { Steel }\end{array}$ & $0.1548 \mathrm{~mm}$ & $0.1375 \mathrm{~mm}$ \\
\hline 3 & $\begin{array}{c}\text { Von misses } \\
\text { Stresses } \\
\text { generated at } \\
\text { Junction }\end{array}$ & $\begin{array}{c}902.06 \mathrm{MPa}( \\
\text { comp })\end{array}$ & $\begin{array}{c}908.71 \mathrm{MPa}( \\
\text { comp) }\end{array}$ \\
\hline 4 & Stress Intensity & $825.49 \mathrm{MPa}$ & $855.47 \mathrm{MPa}$ \\
\hline 5 & $\begin{array}{l}\text { Strain Energy at } \\
\text { the Junction }\end{array}$ & $1.8181 \mathrm{MJ}$ & $1.7135 \mathrm{MJ}$ \\
\hline
\end{tabular}

Table3- (b) Comparison Results of Grey Cast Iron Bush \& Forged Steel of Connecting rod

\begin{tabular}{|c|c|c|c|}
\hline Sr.No & Property & $\begin{array}{c}\text { Theoretical } \\
\text { Value }\end{array}$ & $\begin{array}{c}\text { Analytical } \\
\text { Value by } \\
\text { ANSYS }\end{array}$ \\
\hline 1 & $\begin{array}{l}\text { Deformation in } \\
\text { Brass }\end{array}$ & $0.1457 \mathrm{~mm}$ & O.1406mm \\
\hline 2 & $\begin{array}{c}\text { Deformation in } \\
\text { Steel }\end{array}$ & $0.1548 \mathrm{~mm}$ & $0.1633 \mathrm{~mm}$ \\
\hline 3 & $\begin{array}{l}\text { Von misses } \\
\text { Stresses } \\
\text { generated at } \\
\text { Junction }\end{array}$ & $598.46 \mathrm{Mpa}$ & $542.41 \mathrm{MPa}$ \\
\hline 4 & $\begin{array}{l}\text { Stress Intensity } \\
1210.03\end{array}$ & $1220 \mathrm{MPa}$ \\
\hline 5 & $\begin{array}{l}\text { Strain Energy at } \\
\text { Junction }\end{array}$ & $1.4041 \mathrm{MJ}$ & $1.4103 \mathrm{MJ}$ \\
\hline
\end{tabular}

Table3- (c) Final Result Analysis of Comparison Table

\begin{tabular}{|c|c|c|c|}
\hline $\begin{array}{c}\text { Sr. } \\
\text { No }\end{array}$ & Property & Brass Bush & $\begin{array}{c}\text { Cast iron } \\
\text { Bush }\end{array}$ \\
\hline 1 & $\begin{array}{c}\text { Von misses Stresses } \\
\text { generated at the } \\
\text { Junction }\end{array}$ & $598.46 \mathrm{MPa}$ & $\begin{array}{c}902.06 \mathrm{MPa}(\mathrm{co} \\
\mathrm{mp})\end{array}$ \\
\hline 2 & Deformation & $0.1457 \mathrm{~mm}$ & O.O971mm \\
\hline 3 & Stress Intensity & $1210.03 \mathrm{MPa}$ & $825.49 \mathrm{MPa}$ \\
\hline 4 & $\begin{array}{c}\text { Strain Energy at the } \\
\text { Junction }\end{array}$ & $1.4041 \mathrm{MJ}$ & $1.8181 \mathrm{MJ}$ \\
\hline
\end{tabular}

\section{VII - CONCLUSION}

From the analysis it is clear that material Cast Iron having thermal expansion rate nearer to the steel should be selected as a material for forming bush which is fitted in the Piston end of the Connecting rod. Cast Iron suits best for this application because it has its thermal expansion rate very near to the steel. Apart from the thermal expansion rate the properties like; it "s cost less corrosiveness, frictional properties, etc, makes it best suitable for this type of application. So this analysis focuses on the suitability of the Cast iron bush in place of the Brass bush. This will increase the life of the Connecting rod by avoiding the clearance formation, definitely more than that with Brass bush. So the use of the Cast iron bush becomes more advantageous from all points of view.

\section{REFERENCES}

[1]. Leela Krishna Vegi, VenuGopalVegi , " Design And Analysis of Connecting Rod Using Forged steel”, International Journal of Scientific \&Engineering Research, Vol- 4,Issue 6, June-2013,ISSN 22295518J NT University, Kakinada, AP, INDIA.

[2]. Prof. N.P.Doshi, Prof .N.K.Ingole, “Analysis of Connecting Rod Using Analytical and Finite Element Method", International Journal of Modern Engineering. 2013 pp-65-68 ISSN: 22496645,Sewagram, India.

[3]. Yogesh Kumar Bharti, Vikrant Singh, Afsar Husain, Dipanshu Singh, 'Stress analysis and optimization of connecting rod using finite element analysis", International Journal of Scientific \&Engineering Research, Volume 4, Issue 6, June-2013 1796 ISSN 2229-5518.BIT Gorakhpur, India.

[4]. K. Sudershan Kumar, Dr.K.Tirupathi Reddy, Syed Altaf Husain, "Modeling and Analysis of Two Wheeler Connecting Rod", International Journal of Modern Engineering Research (IJMER), Vol.2, Issue.5, Sep-Oct. 2012 pp-3367.Nandyal,India.

[5]. B.Anushai, Dr.Vijaya Bhaskar Reddy, "Modeling and Analysis of Two Wheeler connecting Rod by using Ansys", Journal of Mechanical \& Civil Engg (IOSR-JMCE), e-ISSN:2278-1684,P-ISSN:2320334x,vol-6, pp 83-87,June 2013.. 